\title{
Diversity and Nesting Substrates of Stingless Bees (Hymenoptera, Meliponina) in a Forest Remnant
}

\author{
Estefane Nascimento Leoncini Siqueira, Bruno Ferreira Bartelli, \\ André Rosalvo Terra Nascimento, and Fernanda Helena Nogueira-Ferreira
}

\begin{abstract}
Instituto de Biologia, Pós-graduação em Ecologia e Conservação de Recursos Naturais, Universidade Federal de Uberlândia, 38400-902 Uberlândia, MG, Brazil

Correspondence should be addressed to Fernanda Helena Nogueira-Ferreira, ferferre@inbio.ufu.br
\end{abstract}

Received 15 August 2012; Accepted 12 September 2012

Academic Editor: Kleber Del-Claro

Copyright ( $) 2012$ Estefane Nascimento Leoncini Siqueira et al. This is an open access article distributed under the Creative Commons Attribution License, which permits unrestricted use, distribution, and reproduction in any medium, provided the original work is properly cited.

\begin{abstract}
Stingless bees are abundant and diverse key actors in several plant-pollinator networks in the neotropics, but little is known about their natural history and ecology. This study aims to contribute to knowledge about the diversity and dispersion of stingless bees and discusses the importance of nesting substrates. It was carried out in the Araguari river valley in Minas Gerais, Brazil, where a nest site survey was conducted in an area of 100 ha during 11 alternate months from 2006 to 2008 , for a total of 1,200 observation hours. Sixty-nine nests were found, belonging to 12 genera and 20 different species. Nests of Melipona rufiventris were by far the most abundant. Stingless bees nested more frequently in hollows of live trees (64\%), and 11 different substrates were identified. Seventeen plant species were used as nesting substrates and Anadenanthera macrocarpa (Fabaceae) was the main host, encompassing $23 \%$ of the surveyed nests. The area studied is important for the maintenance of stingless bees because it provides nesting sites for them. Without nesting sites the reproductive division of colonies is compromised, affecting the nests' survival.
\end{abstract}

\section{Introduction}

Insects comprise the most diverse animal group on the planet, with about 925,000 known species worldwide [1]. They stand out by presenting several adaptations, interacting with various groups of animals and plants and having a large biomass and a wide niche breadth. An important mutualistic interactive mechanism between plants and insects is pollination $[2,3]$, and eusocial bees are responsible for 30 to $50 \%$ of these interactions [4].

The number of bee species in the world is about 30,000 $[5,6]$, and Brazil accounts for an estimated $10 \%$ of this total [7]. The high diversity of bees in Brazil is mainly owed to the tropical climate, which permits perennial nests, and the abundant supply of food. Stingless bees, native to Brazil, are represented by more than 200 species [7] and have a high commercial value because they are pollinators of several native and exotic crops $[8,9]$. Knowledge of the basic ecology of bees is essential for underpinning the development and implementation of conservation strategies [10] and the development of management techniques favoring commercial farmers. In this context, ethological studies on aspects such as foraging ecology, activities such as collecting food resources, material for nests, the demand for sexual partners, and the choice of sites for nests or shelter are extremely relevant.

The choice of nesting site is a stage in the swarming process. The division of reproductive nests in stingless bee colonies starts with a visit by the workers to potential sites for a nest in the vicinity of the parent colony [11]. Most species nest in hollow trees, but many use termite mounds (active or abandoned), anthills, gullies, and crevices in walls, among other places [12]. Nests can be found in different forest environments, such as the Brazilian savanna (Cerrado biome).

The Cerrado is a very old domain. Since the Cretaceous (between 145 and 65 million years ago), there was a precerrado formation. Soon after this period, the uplift of the central plateau and a gradual climate change, to a wetter period, promoted the diversification of flora and 
fauna [13]. The Cerrado biome comprises a mosaic of types of vegetation, ranging from grassland to dense woodland "cerradão". Throughout this gradient of vegetation there is a gradient of biomass, conditioned by natural factors that determine the carrying capacity of the environment and/or by human pressures, especially grazing, frequent fires, and exploitation of wood [14]. The Cerrado covers approximately $22 \%$ of Brazilian territory and has suffered significant human impacts during the past three decades [15], whereas only $1.5 \%$ of this area is protected in conservation areas [16]. One of the regions which has suffered the worst human impact is the westernmost part of the state of Minas Gerais, known as Triângulo Mineiro and located from 18 to $20^{\circ} \mathrm{S}$; 47 to $51^{\circ} \mathrm{W}$, where up to $90 \%$ of the original cover has been wiped out. In this region, native vegetation has been replaced by pastures and cultivated areas [17], or drastically reduced and fragmented. Anthropogenic disturbances influence most organisms, including native bees and other pollinators [18].

Ecological perturbations resulted in a marked turnover of nesting resources, leading in large shifts in the relative proportions of nesting guilds [19]. The abundance of stingless bees' nests is usually related to the availability of appropriate nesting sites, which may act as a limiting resource for these species [20-22]. Other factors that negatively influence stingless bee populations are invasion by exotic species and expansion of agriculture [23], which may even lead undescribed species to extinction [24]. Bees are efficient pollinators contributing to fruit and seed production in different ecosystems [8]. Actually, they may account for 40 to $90 \%$ of native plant pollination, depending on the ecosystem $[25,26]$.

Compared to existing information for areas of temperate forest, knowledge of intra and interspecific ecological relationships that occur in the Cerrado is scarce, as this environment little explored regarding interactive biodiversity [27]. Several studies describe the fauna of stingless bees in the Cerrado through the evaluation and sampling of indivduals visiting floral resources [28-32]. Only a few studies, however, evaluate nest distribution and nesting habits of stingless bees in urban [33-35] and natural areas [35-38]. Although there are several threatened native vegetation remnants in the Triângulo Mineiro region, mostly owing to deforestation and agriculture, there is a lack of information on bee diversity, species composition, and the importance of the plants in their food collection.

To contribute to knowledge about stingless' bees diversity and dispersion, this study describes the nesting sites occupied by various species and discusses the importance of these substrates in the dispersal and maintenance of the species.

\section{Material and Methods}

2.1. Study Area. This study was carried out in the Araguari river valley $\left(18^{\circ} 37^{\prime}, 48^{\circ} 19^{\prime}\right)$, in the municipality of Araguari, Minas Gerais, south-eastern Brazil (Figure 1). The climate is tropical wet (Aw in Köppen's system [39]), and there is a rainy season from October to March and a pronounced dry season from April to September [40]. Annual rainfall ranges from 1,300 to $1,700 \mathrm{~mm}$, and mean monthly temperature shows little variation throughout the year [41].

A nest site survey was conducted in an area of 100 ha that was previously covered mostly with deciduous forest, but there were also a few stretches covered with gallery and semideciduous forests. This area was contiguous to a grazing area, where there were old buildings and cement and wooden poles. The study site is located between 532 and 730 meters above sea level.

2.2. Nest Site Surveys of Stingless Bees. The study was carried out between 2006 and 2008, in 11 alternate months and 1200 observation hours, following random lines established for fauna rescue actions before cleaning and flooding for a dam for hydroelectric power generation. Nest site location was conducted through direct visual search, and each nest position was registered as a geographical coordinate with Global Positioning Systems (GPS).

Nest site location was conducted through direct visual search of tree trunks and termitaria, which were inspected from the base to ten meters' height. The substrate type used for nesting was recorded, and, whenever possible, the nests were transferred to other areas, in order to protect bees against flooding. A few nests which could not be directly transferred to other areas without suffering damage were transferred to wooden boxes and kept in the experimental garden of the Instituto de Biologia (INBIO) at Universidade Federal de Uberlândia (UFU). Voucher specimens of stingless bees and exsiccates of host plants were deposited in the Museu de Biodiversidade do Cerrado (UFU) and Herbarium Uberlandense (UFU, Uberlândia, Minas Gerais, Brazil), respectively.

The entrance of each nest was described and photographed to allow stingless bee species identification. Moreover, individuals belonging to worker castes were also collected and deposited in the following reference collections: Laboratório de Ecologia e Comportamento de Abelhas (LECA) of UFU, Entomological Collection of the Taxonomic Collections of the Universidade Federal de Minas Gerais (UFMG) and Hymenopteran Collection of Faculdade de Filosofia, Ciências e Letras of the Universidade de São Paulo, Campus of Ribeirão Preto (RPSP).

2.3. Data Analysis. Stingless bee species diversity and evenness were calculated with the Shannon-Weaver index $\left(H^{\prime}\right)$ and Pielou index $\left(J^{\prime}\right)$, respectively [42]. In order to detect the type of spatial pattern, the Johnson and Zimmer index of dispersion (I) [43] based on the distance between the sampled points plotted on the map was used.

The precise location of each nest was mapped with ArcView GIS to determine patterns of nest dispersion. We assigned each nest to a substrate type and counted the number of nests belonging to each substrate local. The following substrate types were used: live tree trunk, dead tree trunk, rock substrate, soil, epigeous termitaria, arboreous termitaria, underground termitaria, cement pole, wooden pole, vine, and wall. 


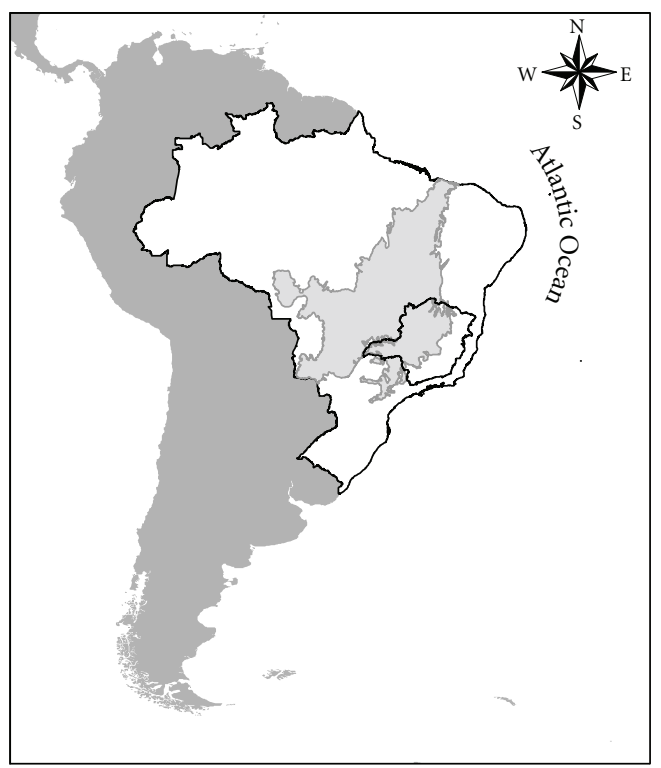

Minas Gerais State

Cerrado Biome

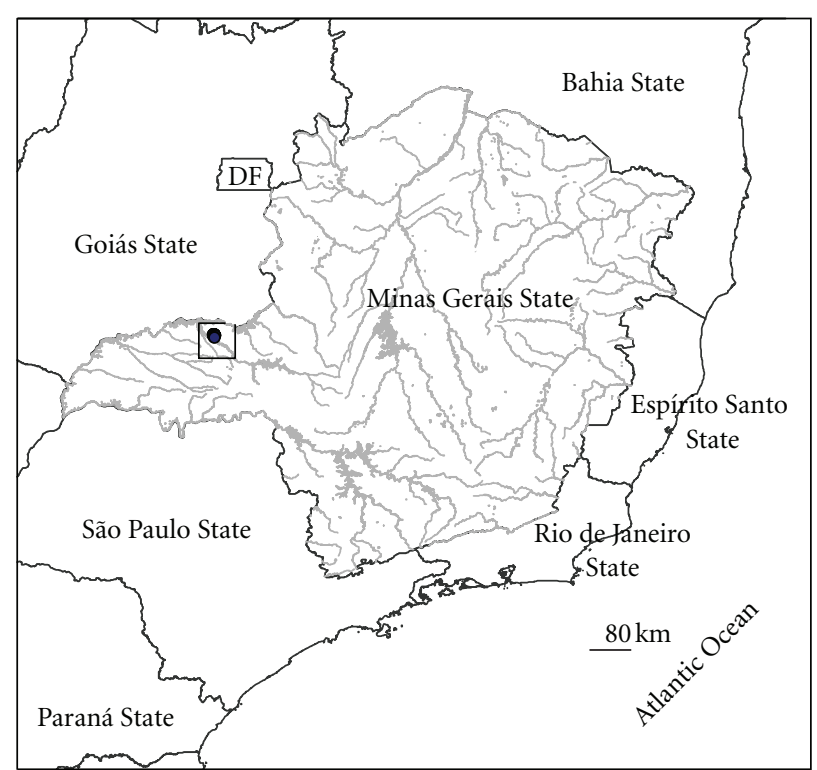

Studied area

(a)

(b)

FIgURE 1: (a) Location of the state of Minas Gerais in Brazil and original extension of Cerrado; (b) Study site location in Minas Gerais.

In order to evaluate patterns of nesting substrate used by the bees, we performed a Principal component analysis (PCA), which ordinates substrate type categories per bee species, using PC-ORD 5.10 version [44]. According to Gauch [45], the first principal component accounts for most variability in the data, and each succeeding component accounts for as much of the remaining variability as possible. In this way, each axis produces an eigenvalue, which corresponds to the relative contribution of that component in explaining the total variance in dataset.

\section{Results}

We found 69 nests of Meliponina bees at the study site, belonging to 12 genera and 20 different species. The bees occupied 11 distinct substrate types (Tables 1 and 2). The genus Trigona presented the highest number of species (six) in the study site, followed by the genera Tetragona, Partamona, and Scaptotrigona, represented by two species each. Regarding nests, Melipona rufiventris Lepeletier, 1836 was the species with highest abundance ( $N=10$ nests), followed by Tetragonisca angustula Latreille, $1811(N=7$ nests) and Scaptotrigona bipunctata Lepeletier, 1836, Tetragona clavipes Fabricius, 1804, Trigona hyalinata Lepeletier, 1836, and Partamona ailyae Camargo, 1980 ( $N=6$ nests) (Table 1).

The diversity of nests of stingless bee species in the study site was $2.68\left(H^{\prime}\right)$, and evenness $\left(J^{\prime}\right)$ was 0.89 , which characterizes a high species' evenness. The 69 nests mapped presented a strongly clumped distribution, since the Johnson and Zimmer index of dispersion $(I)$ was 10.2. This index was calculated for $M$. rufiventris, the most abundant species, and the nests showed a clumped distribution $(I=3.32)$ (Figure 2).

Tetragonisca angustula used a higher number of substrate types (dead tree trunk, live tree trunk, wooden pole, and wall), representing $36.4 \%$ of the total, followed by Frieseomelitta varia Lepeletier, 1836 which used $27.3 \%$ of different substrate types (wall, cement pole, and wooden pole) (Table 1). Some species, however, nested in specific substrates, such as $M$. rufiventris, which used exclusively tree hollows (mostly from live trunks, which represented 90\%). Cephalotrigona capitata Smith, 1874, Scaptotrigona bipunctata Lepeletier, 1836, and Tetragona clavipes Fabricius, 1804 nested exclusively in live trunks. On the other hand, Partamona combinata Pedro and Camargo, 2003, Trigona recursa Smith, 1863, and Trigona fulviventris Guérin, 1837 nested only in sites associated with termites (Table 1). Most nests were located in hollows of live trunks (64\%), which were occupied by 14 different stingless bee species (Table 2). Seventeen plant species were used as substrate for nesting, and Anadenanthera macrocarpa (Benth.) Brenan (Fabaceae) was the commonest one (Table 3 ).

The Principal component analysis (Figure 3) pooled substrates in at least two major groups, according to distance from ground level, showing similarities between nesting habitats of some species of bees. The first group was composed of substrates located at ground level (rock, dead trunk, and underground termitaria), which presented similar values for both ordination axes. Substrates located above ground (cement pole and wooden pole) formed a second group, situated at the center of the ordination. The ecological 


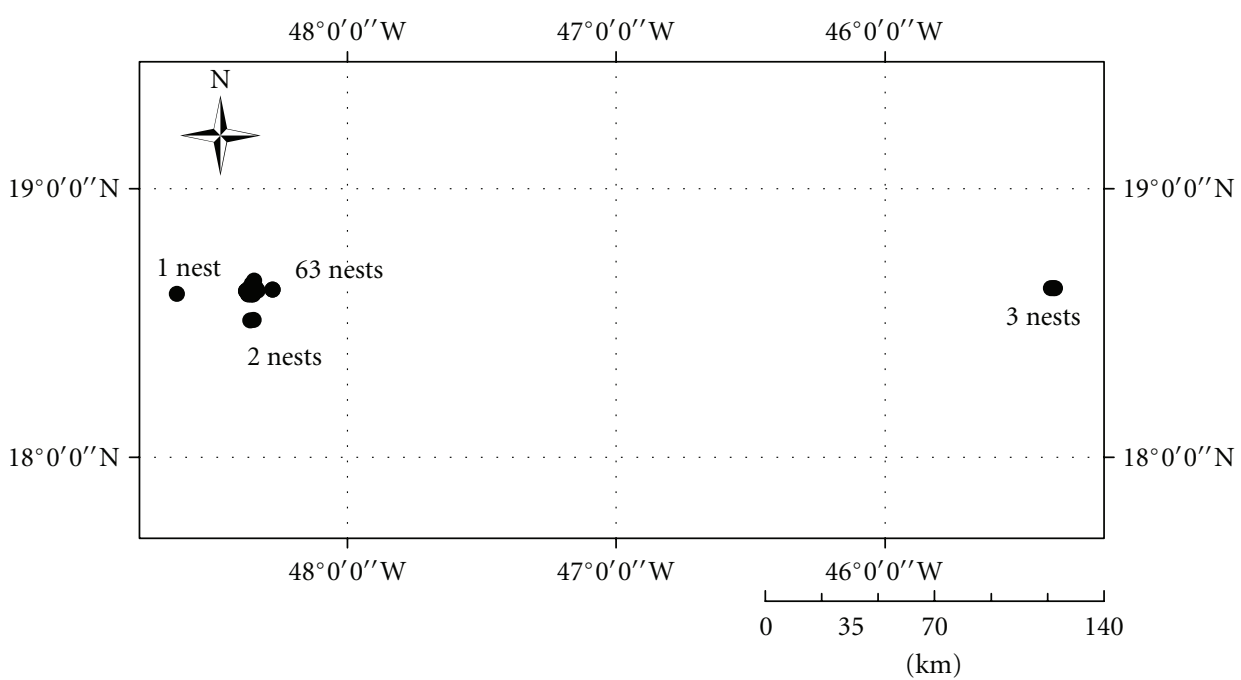

(a)

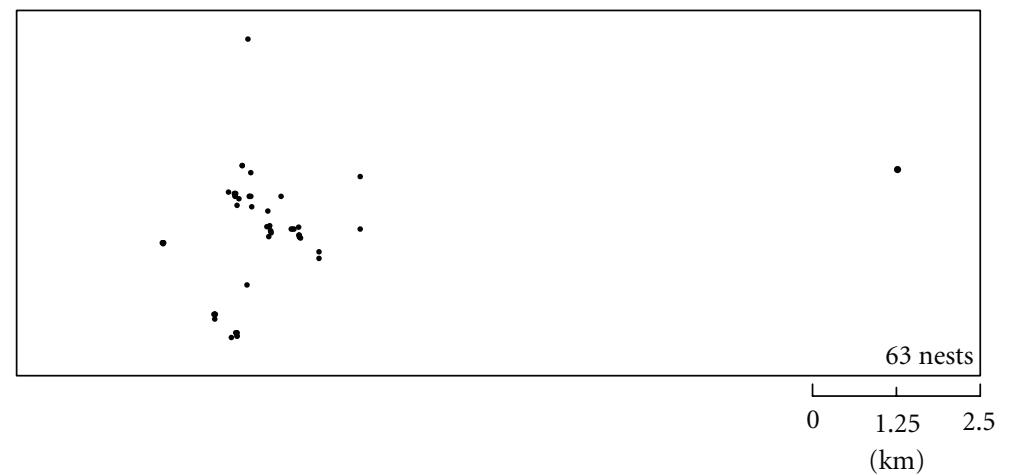

(b)

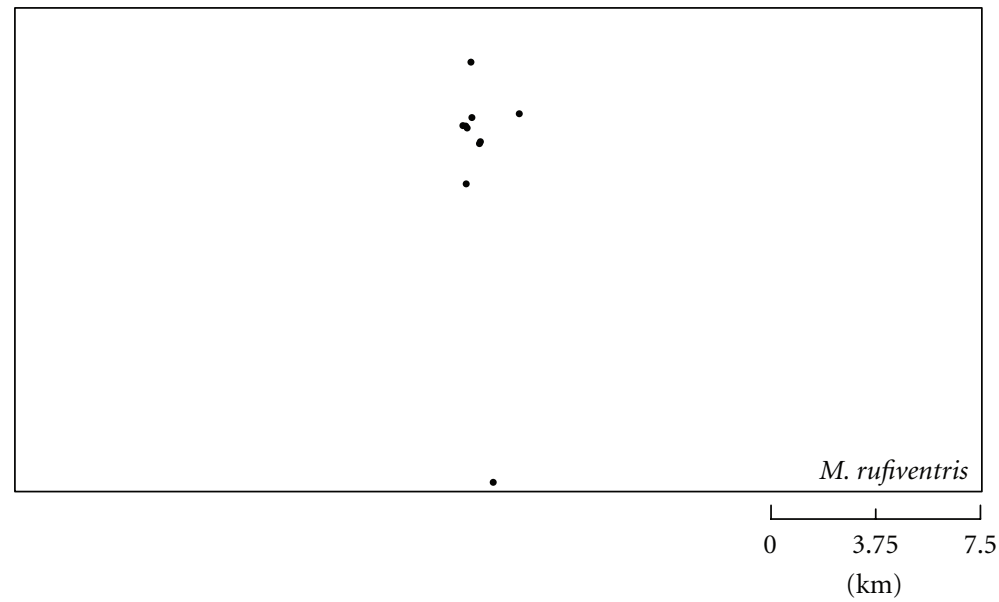

(c)

Figure 2: (a) Spatial distribution of the 69 nests of stingless bees in the study area mapped. (b) Spatial distribution of the 63 nests presented in Figure 2(a), on a large scale. (c) Spatial distribution of the 10 nests of M. rufiventris mapped in the study area.

preference for live trunk substrate was found in the analysis, through the placement of this category in the central portion of the ordination. On the other hand, substrates that were seldom used (e.g., arboreus termitaria, murundum termit and vines) presented lower values from the second axis, and failed to form groups with most substrates present in the ordination. The first axis explained $61.8 \%$ of the variance in the dataset, while the second axis explained only $7.21 \%$. 
TABLE 1: Number of nests and substrate types used by each stingless bee species in a forest fragment located in the municipality of Araguari, Minas Gerais, Brazil.

\begin{tabular}{|c|c|c|}
\hline Bee species & Number of nests & Nesting substrate category* \\
\hline (1) Cephalotrigona capitata (Smith, 1874) & 03 & $f, f, f$ \\
\hline (2) Frieseomelitta varia (Lepeletier,1836) & 03 & $e, g, h$ \\
\hline (3) Lestrimelitta limao (Smith,1863) & 01 & $\mathrm{f}$ \\
\hline (4) Melipona rufiventris (Lepeletier, 1836) & 10 & $b, f, f, f, f, f, f, f, f, f$ \\
\hline (5) Oxytrigona tataira (Smith, 1863) & 01 & $\mathrm{f}$ \\
\hline (6) Partamona ailyae (Camargo, 1980) & 06 & $f, f, f, f, f, k$ \\
\hline (7) Partamona combinata (Pedro and Camargo, 2003) & 03 & $\mathrm{j}, \mathrm{j}, \mathrm{k}$ \\
\hline (8) Plebeia droryana (Friese, 1900) & 01 & $\mathrm{f}$ \\
\hline (9) Scaptotrigona bipunctata (Lepeletier, 1836) & 06 & $f, f, f, f, f, f$ \\
\hline (10) Scaptotrigona depilis (Moure, 1942) & 04 & $\mathrm{~b}, \mathrm{f}, \mathrm{f}, \mathrm{f}$ \\
\hline (11) Scaura longula (Lepeletier, 1836) & 01 & $\mathrm{f}$ \\
\hline (12) Tetragona clavipes (Fabricius, 1804) & 06 & $f, f, f, f, f, f$ \\
\hline (13) Tetragona quadrangula (Lepeletier, 1836) & 02 & $\mathrm{f}, \mathrm{f}$ \\
\hline (14) Tetragonisca angustula (Latreille, 1811) & 07 & $b, e, f, f, f, f, h$ \\
\hline (15) Trigona fulviventris (Guérin, 1837) & 02 & $c, c$ \\
\hline (16) Trigona hyalinata (Lepeletier, 1836) & 06 & $a, f, f, f, f, f$ \\
\hline (17) Trigona hypogea (Silvestri, 1902) & 02 & $d, f$ \\
\hline (18) Trigona recursa (Smith, 1863) & 02 & $\mathrm{k}, \mathrm{k}$ \\
\hline (19) Trigona spinipes (Fabricius, 1793) & 02 & $\mathrm{i}, \mathrm{i}$ \\
\hline (20) Trigona truculenta (Almeida, 1985) & 01 & $\mathrm{a}$ \\
\hline
\end{tabular}

*a: rock substrate, b: dead trunk, c: underground termitaria, d: soil, e: wall, f: live trunk, g: cement pole, h: wooden pole, i: vine, j: arboreous termitaria, k: epigeous termitaria.

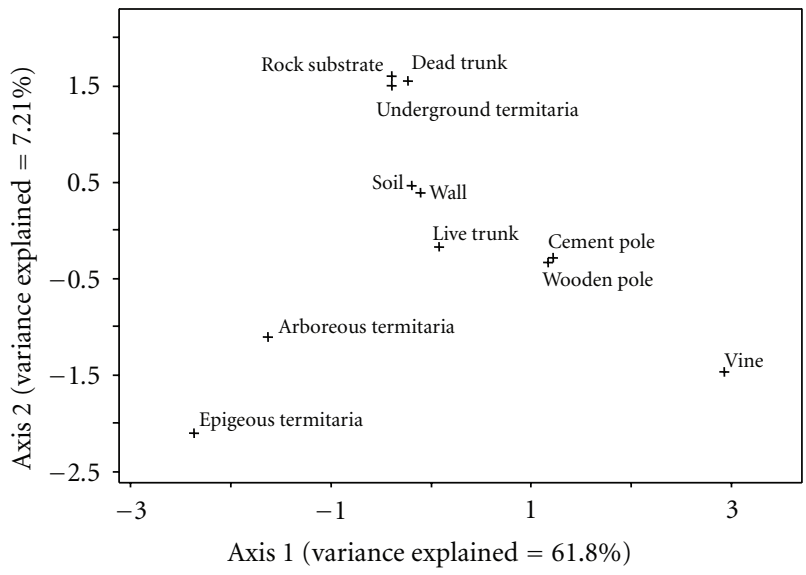

FIGURe 3: Principal component analysis (PCA) ordinating substrate types used for nesting per twenty stingless bee species that occurred in a forest fragment located in the municipality of Araguari, Minas Gerais, Brazil.

\section{Discussion}

Different substrates were used by stingless bees as shelters in which to nidify inside the dry forests that include different physiognomies contiguous to a grazing area. This characteristic of the dry forests may account for the abundance of stingless bee samples whereby the nesting success includes the abundance, size, and species of trees [46, 47]. Suitable
TABLE 2: Number of stingless bee nests for each substrate type, and number of species nesting for each substrate in a forest fragment located in the municipality of Araguari, Minas Gerais, Brazil.

\begin{tabular}{lcc}
\hline Substrate type & $\begin{array}{c}\text { Number of } \\
\text { nests }\end{array}$ & $\begin{array}{c}\text { Number of species } \\
\text { using the substrate }\end{array}$ \\
\hline (1) Cement pole & 1 & 1 \\
(2) Dead trunk & 6 & 3 \\
(3) Epigeous termitaria & 4 & 3 \\
(4) Live trunk & 44 & 14 \\
(5) Rock substrate & 2 & 2 \\
(6) Soil & 1 & 1 \\
(7) Arboreous termitaria & 2 & 1 \\
(8) Underground termitaria & 3 & 1 \\
(9) Vine & 2 & 1 \\
(10) Wall & 2 & 2 \\
(11) Wooden pole & 2 & 2 \\
\hline
\end{tabular}

nesting sites are considered limiting resources for stingless bees $[21,25]$, whereas the availability of materials used in nest construction, food supply, and natural enemies [48] is also important for the survival and reproduction of species. These factors also appear to be relevant for other social invertebrates such as ants [49] and pseudoscorpions [50].

Owing to the peculiar swarming activity in Meliponina, which limits maximum flight distance, the distance between appropriate nesting sites, and the connectivity between 
TABLE 3: Plant species used as nesting substrate by stingless bee species, and number of nests per bee species in each different plant in a forest fragment located in the municipality of Araguari, Minas Gerais, Brazil.

\begin{tabular}{|c|c|c|c|}
\hline Plant species & Stingless bee species & $\begin{array}{c}\text { Nests number/stingless } \\
\text { bee species/plant }\end{array}$ & Total nests/plant \\
\hline \multirow{10}{*}{ (1) Anadenanthera macrocarpa (Benth.) Brenan (Fabaceae) } & Cephalotrigona capitata & 1 & \multirow{10}{*}{16} \\
\hline & Lestrimelitta limao & 1 & \\
\hline & Melipona rufiventris & 1 & \\
\hline & Oxytrigona tataira & 1 & \\
\hline & Partamona ailyae & 3 & \\
\hline & Scaptotrigona bipunctata & 3 & \\
\hline & Scaptotrigona depilis & 1 & \\
\hline & Tetragona clavipes & 3 & \\
\hline & Tetragonisca angustula & 1 & \\
\hline & Trigona hyalinata & 1 & \\
\hline \multirow{2}{*}{ (2) Caryocar brasiliense Camb. (Caryocaraceae) } & Melipona rufiventris & 1 & \multirow{2}{*}{2} \\
\hline & Tetragona quadrangula & 1 & \\
\hline (3) Chorisia speciosa A. St.-Hil. (Malvaceae) & Trigona hyalinata & 2 & 2 \\
\hline \multirow{2}{*}{ (4) Copaifera langsdorffii Desf. (Fabaceae) } & Scaptotrigona bipunctata & 1 & \multirow[b]{2}{*}{2} \\
\hline & Tetragonisca angustula & 1 & \\
\hline (5) Dipteryx alata Vogel (Fabaceae) & Tetragonisca angustula & 1 & 1 \\
\hline \multirow{2}{*}{ (6) Ficus sp. (Moraceae) } & Melipona rufiventris & 1 & \multirow[b]{2}{*}{2} \\
\hline & Tetragonisca angustula & 1 & \\
\hline \multirow{4}{*}{ (7) Guapira sp. (Nyctaginaceae) } & Cephalotrigona capitata & 1 & \multirow{4}{*}{4} \\
\hline & Melipona rufiventris & 1 & \\
\hline & Plebeia droryana & 1 & \\
\hline & Scaptotrigona bipunctata & 1 & \\
\hline \multirow{2}{*}{ (8) Hymenaea courbaril L. (Fabaceae) } & Tetragona clavipes & 1 & \multirow[b]{2}{*}{3} \\
\hline & Trigona hyalinata & 2 & \\
\hline \multirow{2}{*}{ (9) Myracrodruon urundeuva Fr. All. (Anacardiaceae) } & Partamona ailyae & 1 & \multirow[b]{2}{*}{2} \\
\hline & Trigona hypogea & 1 & \\
\hline (10) Pouteria ramiflora (Mart.) Radlk. (Sapotaceae) & Melipona rufiventris & 1 & 1 \\
\hline (11) Qualea parviflora Mart. (Vochysiaceae) & Cephalotrigona capitata & 1 & 1 \\
\hline (12) Sclerolobium aureum (Tul.) Benth. (Fabaceae) & Melipona rufiventris & 1 & 1 \\
\hline $\begin{array}{l}\text { (13) Senna rugosa (G.Don) H.S. Irwin and Barneby } \\
\text { (Fabaceae) }\end{array}$ & Scaura longula & 1 & 1 \\
\hline (14) Stryphnodendron adstringens (Mart.) Cov. (Fabaceae) & Melipona rufiventris & 1 & 1 \\
\hline \multirow{3}{*}{$\begin{array}{l}\text { (15) Tabebuia aurea (Manso) Benth. and Hook.f. ex S. } \\
\text { Moore (Bignoniaceae) }\end{array}$} & Melipona rufiventris & 1 & \multirow{3}{*}{3} \\
\hline & Partamona ailyae & 1 & \\
\hline & Tetragona clavipes & 1 & \\
\hline (16) Tapirira guianensis Aubl. (Anacardiaceae) & Tetragona clavipes & 1 & 1 \\
\hline (17) Terminalia argentea Mart. et Zucc. (Combretaceae) & Tetragona quadrangula & 1 & 1 \\
\hline
\end{tabular}

fragmented habitats directly influence the dispersion ability of bees and species-genetic variability. Disparate forest fragments may attract only limited colonization by stingless bees because, during the swarming process, the colony that is formed depends on food and materials for nest construction provided by the maternal nest for some days [5, 51]. Consequently, to allow successful dispersal, nesting sites should be within worker bees' flight range, and well-preserved fragmented areas should be connected. The present study confirmed the importance of maintaining the study area that functions as a provider of nest sites for stingless bees. This is a fundamental condition for the survival of these species, because otherwise the reproductive division of the colony is compromised, affecting nest survival and consequently the 
dispersion of the species. Thus, the maintenance of natural areas close to each other is essential.

Although 17 plant species were used as nesting substrate, Anadenanthera macrocarpa was the main substrate used by nesting bees. The suitability of $A$. macrocarpa as a nesting substrate may be related to its large trunk diameter, which presents larger natural cavities in contrast to most Cerrado plant species that present thin and contorted trunks. The preference for some plant species is reported by previous authors, in that more than $61 \%$ of nests were encountered in only two species of tree $[36,38]$. The diversity of bee genera found in this study represents $60 \%$ of all genera occurring in Minas Gerais state, and as regards species this value is about $41 \%$ compared with data presented in a systematic study of stingless bees by Silveira et al. [7].

This study was carried out in a forest remnant that includes at least three different physiognomies presented in such a way that habitat heterogeneity contiguous to a grazing area may account for the abundance of stingless bee samples. This characteristic could explain the bee species' richness and the nest dispersion, which provides a wide variety of nesting sites and food resources, thus facilitating species' coexistence through resource partitioning. Stingless bees constructed their nests mostly in hollows of live tree trunks; hence, deforestation greatly influences their community structure and population dynamics [52] owing to a decrease in the availability of nesting sites and food supply.

Studies which try to explain the diversity of stingless bees through a search for nests are scarce because of difficulties imposed by the search method, which can actually increase depending on the vegetation and topography of the area in question. Environments consisting of low and open vegetation the nests can be found more easily. However, in high vegetation with closed canopy the application of this method becomes more difficult.

The aggregated pattern of distribution of nests should be correlated with the composition of existing vegetation in the study area. The nests were mostly found in places where there are trees with thicker trunks, in semideciduous forest in the savanna and in areas adjacent to pastures, where many trees have been preserved. The same is true of $M$. rufiventris, whose nests were found mainly near streams in areas of gallery forest (Siqueira, pers. comm.). In studies of Trigona collina, species in a mixed area of deciduous forest in Thailand had a strongly clumped nest distribution [37]. Serra et al. [38], studying three different areas of disturbed savanna vegetation, found for two of them a random pattern that was understood as the absence of competition for food resources. The pattern of spatial distribution of nests is possibly related to extrinsic factors such as distribution and density of suitable substrates for nest construction, the ecological aspects of occupancy of hollows, predation [38] and related features of the swarming process [37].

According to Laroca [53], bee communities usually follow a lognormal distribution, in which a few species are rare or highly dominant, and most species present moderate abundance. Our data on nest abundance of stingless bees fit with this species-abundance relationship.
Some studies evaluated stingless bee nest diversity in Brazilian Cerrado areas. In the Araguari river valley, nest diversity was higher than that found by Serra et al. [38] and Mateus et al. [35]. Serra et al. [38] studied a Cerrado area of 114 ha in the state of Maranhão (north of Brazil) and found 40 nests belonging to ten Meliponina species. In a natural Cerrado area in Nova Xavantina (Mato Grosso, central Brazil), Mateus et al. [35] found 34 nests belonging to seven genera and 12 species. Maia et al. [54] found seven different species nesting in trunks in a gallery forest area in a Cerrado area in the state of Maranhão (north of Brazil). In the latter study, $M$. rufiventris was more abundant than other species, which is in accordance with our results.

Carvalho and Bego [29] sampled bees visiting floral resources in a Cerrado area near our study site and found nine genera and 11 Meliponina species. Considering the methodological differences and the difficulty of finding bee nests in the wild, our results suggest that bee species' richness is almost twice as high in our study site as that of Carvalho and Bego [29], which reinforces the importance of protecting our study site.

M. rufiventris is considered a specialist in flowers occurring in well-preserved areas [55], and it presents a strong connection with water courses, as nests are usually found close to or along river margins [56]. This species, along with $P$. combinata, was in the IUCN Red Lists for the state of Minas Gerais [57]. In addition to habitat specialist species, the Araguari river valley stingless bee community retains several rare species, including Melipona quadrifasciata, Melipona quinquefasciata, Partamona helleri, Plebeia remota, Nannotrigona testaceicornis and Schwarziana quadripunctata (Siqueira, pers. comm.). These species were added to the community through sporadic observations of bees visiting flowers. Hence, we suggest that (1) the study site is important in terms of maintaining stingless bee species' diversity, (2) future studies using methods ranging from nest surveys to direct collection of bees visiting flowers could increase the observed Meliponina species' richness in the study site, and (3) management plans and conservation actions should be employed in order to protect the diversity of stingless bees in Cerrado biome.

\section{Acknowledgments}

The authors are indebted to Fernando A. Silveira and Silvia R. M. Pedro for bee identification, to Glein Araújo and Ivan Schiavini for plant identification, to André Nemésio, Maria Cristina Gaglianone, and Kleber Del Claro for suggestions that improved the final version of the manuscript and to Camila N. Junqueira for the ArcView GYS Program work. They are also grateful to Roderic Breno Martines for help with fieldwork and Consórcio Capim Branco, especially Simone Mendes and Diogo Lemos, for authorizing data collection. CNPq and FAPEMIG provided financial support, and the Instituto de Biologia (Universidade Federal de Uberlândia) provided logistical support. 


\section{References}

[1] D. Grimaldi and M. S. Engel, Evolution of the Insects, Cambridge University Press, New York, NY, USA, 2005.

[2] P. G. Kevan and H. G. Baker, "Insects as flower visitors and pollinators," Annual Review of Entomology, vol. 28, pp. 407453, 1983.

[3] M. Proctor, P. Yeo, and A. Lack, The Natural History of Pollination, Harper Collins, London, UK, 1996.

[4] J. C. Biesmeijer, E. J. Slaa, M. S. Castro, B. F. Viana, A. M. P. Kleinert, and V. L. Imperatriz-Fonseca, "Connectance of Brazilian social bees-food plant networks is influenced by habitat, but not by latitude, altitude or network size," Biota Neotropica, vol. 5, no. 1, pp. 85-93, 2005.

[5] D. W. Roubik, Ecology and Natural History of Bees, Cambridge University Press, Cambridge, UK, 1989.

[6] C. D. Michener, The Bees of the World, The Johns Hopkins University Press, Baltimore, Md, USA, 2000.

[7] F. A. Silveira, G. A. R. Mello, and E. A. B. Almeida, Abelhas Brasileiras: Sistemática e Identificação, Fernando A. Silveira, Belo Horizonte, Brazil, 2002.

[8] M. S. Castro, D. Koedam, and F. A. L. Contrera, "Stingless bees," in Bees as Polinators in Brazil: Assessing the Status and Suggesting Best Practices, V. L. Imperatriz-Fonseca, Ed., p. 112, Holos Editora, Ribeirão Preto, Brazil, 2006.

[9] B. M. Freitas and P. Nunes-Silva, "Polinização agrícola e sua importância no Brasil," in Polinizadores no Brasil. Contribuição e Perspectivas Para a Biodiversidade, Uso Sustentável, Conservação e Serviços Ambientais, V. L. ImperatrizFonseca, Ed., 2012.

[10] A. Byrne and Ú. Fitzpatrick, "Bee conservation policy at the global, regional and national levels," Apidologie, vol. 40, no. 3, pp. 194-210, 2009.

[11] J. W. Van Veen and M. J. Sommeijer, "Observations on gynes and drones around nuptial flights in the stingless bees Tetragonisca angustula and Melipona beecheii (Hymenoptera, Apidae, Meliponinae)," Apidologie, vol. 31, no. 1, pp. 47-54, 2000.

[12] P. Nogueira-Neto, A Criação de Abelhas Indígenas sem Ferrão, Editora Nogueirapis, São Paulo, Brazil, 1970.

[13] R. B. Machado, L. S. Aguiar, A. A. J. F. Castro, C. C. Nogueira, and M. B. Ramos Neto, "Caracterização da fauna e flora do Cerrado," in Savanas: Desafios e Estratégias para o Equilíbrio Entre Sociedade, Agronegócio e Recursos Naturais, F. G. Faleiro and A. L. Farias Neto, Eds., pp. 285-300, Embrapa Cerrados, Planaltina, Brazil, 2008.

[14] G. Durigan, "Bases e diretrizes para a restauração da vegetação de Cerrado," in Restauração Ecológica de Ecossistemas Naturais, P. Y. Kageyama, R. E. Oliveira, L. F. D. Moraes, V. L. Engel, and F. B. Gandara, Eds., p. 340, FEPAF, Botucatu, Brazil, 2008.

[15] W. Jepson, "A disappearing biome? Reconsidering land-cover change in the Brazilian savanna," Geographical Journal, vol. 171, no. 2, pp. 99-111, 2005.

[16] R. A. Mittermeier, N. Myers, P. R. Gil, and C. G. Mittermeier, "Hotspots: earth's biologically richest and most endangered terrestrial ecoregions," CEMEX, Mexico City, Mexico, 1999.

[17] P. S. Oliveira and R. J. Marquis, "The cerrados of Brazil: Ecology and natural history of a neotropical savanna," Columbia University Press, New York, NY, USA, 2002.

[18] J. Donaldson, I. Nänni, C. Zachariades, and J. Kemper, "Effects of habitat fragmentation on pollinator diversity and plant reproductive success in renosterveld shrublands of South
Africa," Conservation Biology, vol. 16, no. 5, pp. 1267-1276, 2002.

[19] S. G. Potts, B. Vulliamy, S. Roberts et al., "Role of nesting resources in organising diverse bee communities in a Mediterranean landscape," Ecological Entomology, vol. 30, no. 1, pp. 78-85, 2005.

[20] W. E. Kerr, S. F. Sakagami, R. Zucchi, V. Portugal-Araújo, and J. M. Camargo, "Observações sobre a arquitetura dos ninhos e comportamento de algumas espécies de abelhas sem ferrão das vizinhanças de Manaus, Amazonas (Hymenoptera, Apoidea)," Atas do Simpósio Sobre a Biota Amazônica 5 (Zoologia), pp. 255-309, 1967.

[21] J. M. F. Camargo, "Ninhos e algumas espécies de Meliponídeos (Hymenoptera, Apidae) da região de Porto Velho, território de Rondônia, Brasil," Revista de Biologia Tropical, vol. 16, pp. 207-239, 1970.

[22] C. K. Starr and S. F. Sakagami, "An extraordinary concentration of stingless bee colonies in the Philippines, with notes on nest structure (Hymenoptera: apidae:Trigona spp.)," Insectes Sociaux, vol. 34, no. 2, pp. 96-107, 1987.

[23] B. M. Freitas, V. L. Imperatriz-Fonseca, L. M. Medina et al., "Diversity, threats and conservation of native bees in the Neotropics," Apidologie, vol. 40, no. 3, pp. 332-346, 2009.

[24] W. M. Schaffer, D. W. Zeh, S. L. Buchmann, S. Kleinhans, M. V. Schaffer, and J. Antrim, "Competition for nectar between introduced honey bees and native North American bees and ants," Ecology, vol. 64, no. 3, pp. 564-577, 1983.

[25] W. E. Kerr, G. A. Carvalho, and V. A. Nascimento, Abelha Uruçu: Biologia, Manejo e Conservação, Fundação Acangaú, Belo Horizonte, Brazil, 1996.

[26] I. Silberbauer-Gottsberger and G. Gottsberger, "A polinização de plantas do cerrado," Revista Brasileira de Biologia, vol. 48, pp. 651-663, 1988.

[27] K. Del-Claro and H. M. Torezan-Silingardi, "Insect-plant interactions: new pathways to a better comprehension of ecological communities in Neotropical savannas," Neotropical Entomology, vol. 38, no. 2, pp. 159-164, 2009.

[28] F. A. Silveira and M. J. O. Campos, "A melissofauna de Corumbataí (SP) e Paraobeba (MG): uma análise da biogeografia das abelhas do cerrado brasileiro (Hymenoptera: Apoidea)," Revista Brasileira de Entomologia, vol. 39, no. 2, pp. 371-401, 1995.

[29] A. M. C. Carvalho and L. R. Bego, "Studies on Apoidea fauna of cerrado vegetation at the Panga Ecological Reserve, Uberlândia, MG, Brazil," Revista Brasileira de Entomologia, vol. 40, pp. 147-156, 1996.

[30] A. M. C. Carvalho and L. R. Bego, "Exploitation of available resources by bee fauna (Apoidea-Hymenoptera) in the Reserva Ecológica do Panga, Uberlândia, state of Minas Gerais, Brazil," Revista Brasileira de Entomologia, vol. 41, pp. 101-107, 1997.

[31] S. E. M. Pedro, "Meliponini Neotropicais: O gênero Partamona Schawrz, 1939 (Hymenoptera, Apidae): Taxonomia e Biogeografia," Tese de Doutorado-Faculdade de Filosofia, Ciências e Letras de Ribeirão Preto, Universidade de São Paulo, Ribeirão Preto/SP, 1998.

[32] S. Mateus, "Abundância relativa, fenologia e visita as flores pelos Apoidea do Cerrado da Estação Ecológica de Jataí, Luiz Antônio-SP," Dissertação (Mestrado em Entomologia)Faculdade de Filosofia, Ciências e Letras de Ribeirão Preto, Universidade de São Paulo, Ribeirão Preto/SP, 1998.

[33] H. M. Taura and S. Laroca, "Abelhas altamente sociais (Apidae) de uma área restrita em Curitiba (Brasil): distribuição dos 
ninhos e abundância relativa," Acta Biologica Paranaense, vol. 20, pp. 85-101, 1991.

[34] G. S. Freitas, "Levantamento de ninhos de meliponineos (Hymenoptera, Apidae) em área urbana: Campus da USP, Ribeirão Preto/SP,” Dissertação de Mestrado-Faculdade de Filosofia Ciências e Letras de Ribeirão Preto, Universidade de São Paulo, Ribeirão Preto/SP, 2001.

[35] S. Mateus, U. C. R. Pereira, H. S. R. Cabette, and R. Zucchi, "Locais de nidificação das abelhas nativas sem ferrão (Hymenoptera, Apidae, Meliponinae) do parque municipal do Bacaba, Nova Xavantina MT," Mensagem Doce, vol. 1, pp. 6062, 2009.

[36] C. F. Martins, M. Cortopassi-Laurino, D. Koedam, and V. L. Imperatriz-Fonseca, "Espécies arbóreas utilizadas para nidificação por abelhas sem ferrão na Caatinga (Seridó, PB; João Câmara, RN)," Biota Neotropica, vol. 4, pp. 1-8, 2004.

[37] T. Jongjitvimol, K. Boomtown, K. Wattanachaiyingcharoen, and S. Deowanish, "Nest dispersion of a stingless bee species, Trigona collina Smith, 1857 (Apidae, Meliponinae) in a mixed deciduous forest in Thailand," The Natural History Journal of Chlalongkorn University, vol. 5, pp. 69-71, 2005.

[38] B. D. V. Serra, M. S. Drummond, L. M. Lacerda, and I. P. Akatsu, 'Abundance, space distribution of bees' nests Meliponina (Hymenoptera, Apidae, Apini) and vegetable sorts used for nidificação in areas of scrubland of the Maranhão," Iheringia, Serie Zoologia, vol. 99, no. 1, pp. 12-17, 2009.

[39] W. Köppen, Climatologia: Con un Estudio de los Climas de la Terra, Fondo de Cultura Económica, México, 1948.

[40] R. L. Vianell and o and A. R. Alves, Meteorologia Básica a Aplicações, UFV, Viçosa, Brazil, 2000.

[41] R. Rosa, S. C. Lima, and W. L. Assunção, "Abordagem preliminar das condições climáticas de Uberlândia (MG)," Sociedade \& Natureza, vol. 1, pp. 91-108, 1991.

[42] A. E. Magurran, Measuring Biological Diversity, Blackwell, Oxford, UK, 2004.

[43] J. A. Ludwig and J. F. Reynolds, Statistical Ecology: A Primer on Methods and Computing, Wiley-Intersciencie, New York, NY, USA, 1988.

[44] B. Mccune and M. J. Mefford, PC-ORD Multivariate Analysis of Ecological Data, MjM Software, Gleneden Beach, Ore, USA, 2006.

[45] H. G. Gauch, Multivariate Analysis in Community Ecology, Cambridge University Press, New York, NY, USA, 1982.

[46] T. Eltz, C. A. Brühl, and C. Görke, "Collection of mold (Rhizopus sp.) spores in lieu of pollen by the stingless bee Trigona collina," Insectes Sociaux, vol. 49, no. 1, pp. 28-30, 2002.

[47] H. Samejima, M. Marzuki, T. Nagamitsu, and T. Nakasizuka, "The effects of human disturbance on a stingless bee community in a tropical rainforest," Biological Conservation, vol. 120, no. 4, pp. 577-587, 2004.

[48] S. Salmah, T. Inoue, and S. F. Sakagami, "An analysis on apid bees richnesses (Apidae) in central Sumatra," in Natural History of Social Wasps and Bees in Equatorial Sumatra, R. Ohgushi, S. F. Sakagami, and K. D. W. Roubik, Eds., pp. 139174, Hokaido University Press, Sapporo, Japan, 1990.

[49] M. Yamamoto and K. Del-Claro, "Natural history and foraging behavior of the carpenter ant Camponotus sericeiventris Guérin, 1838 (Formicinae, Campotonini) in the Brazilian tropical savanna," Acta Ethologica, vol. 11, no. 2, pp. 55-65, 2008.

[50] E. Tizo-Pedroso and K. Del-Claro, "Is there division of labor in cooperative pseudoscorpions? an analysis of the behavioral repertoire of a tropical species," Ethology, vol. 117, no. 6, pp. 498-507, 2011.

[51] F. H. Nogueira-Ferreira and A. E. E. Soares, "Male aggregations and mating flight in Tetragonisca angustula (Hymenoptera, Apidae, Meliponinae)," Iheringia Serie Zoologia, vol. 84, pp. 141-144, 1998.

[52] C. Kremen, N. M. Williams, R. L. Bugg, J. P. Fay, and R. W. Thorp, "The area requirements of an ecosystem service: crop pollination by native bee communities in California," Ecology Letters, vol. 7, no. 11, pp. 1109-1119, 2004.

[53] S. Laroca, "Community ecology in bees: relative importance of rare and common species in some Holartic and Neotropical sites," Revista Brasileira de Zoologia, vol. 9, pp. 131-137, 1992.

[54] C. M. Maia, M. S. Drumond, and L. M. Lacerda, "Estrutura de comunidade de abelhas Meliponinae (Apidae, Hymenoptera) em área de Mata Ciliar (Urbano Santos-MA)," in Anais do V Encontro Sobre Abelhas, C. A. Garófalo, Ed., p. 269, Faculdade de Filosofia, Ciências e Letras de Ribeirão Preto, 5, Ribeirão Preto, Brazil, 2002.

[55] A. G. Damasceno, "Abelhas (Hymenoptera, Apoidea) visitantes das inflorescências da sucupira-branca, Pterodum emarginatus Vogel (Leguminosae: Papilionoidae) e do baru, Dipteryx alata Vogel (Leguminosae: Papilionoidae) em área de Cerrado em Brasilândia de Minas-MG,” Dissertação de Mestrado-Universidade Federal de Lavras, Lavras/MG, 1998.

[56] E. N. L. Siqueira, R. B. Martines, and F. H. Nogueira-Ferreira, "Ninhos de abelhas sem ferrão (Hymenoptera, Meliponina) em uma região do Rio Araguari, Araguari-MG," Bioscience Journal, vol. 23, pp. 38-44, 2007.

[57] A. B. M. Machado, Livro Vermelho das Espécies Ameaçadas de Extinção da Fauna em Minas Gerais, Fundação Biodiversitas, Belo Horizonte, Brazil, 1998. 

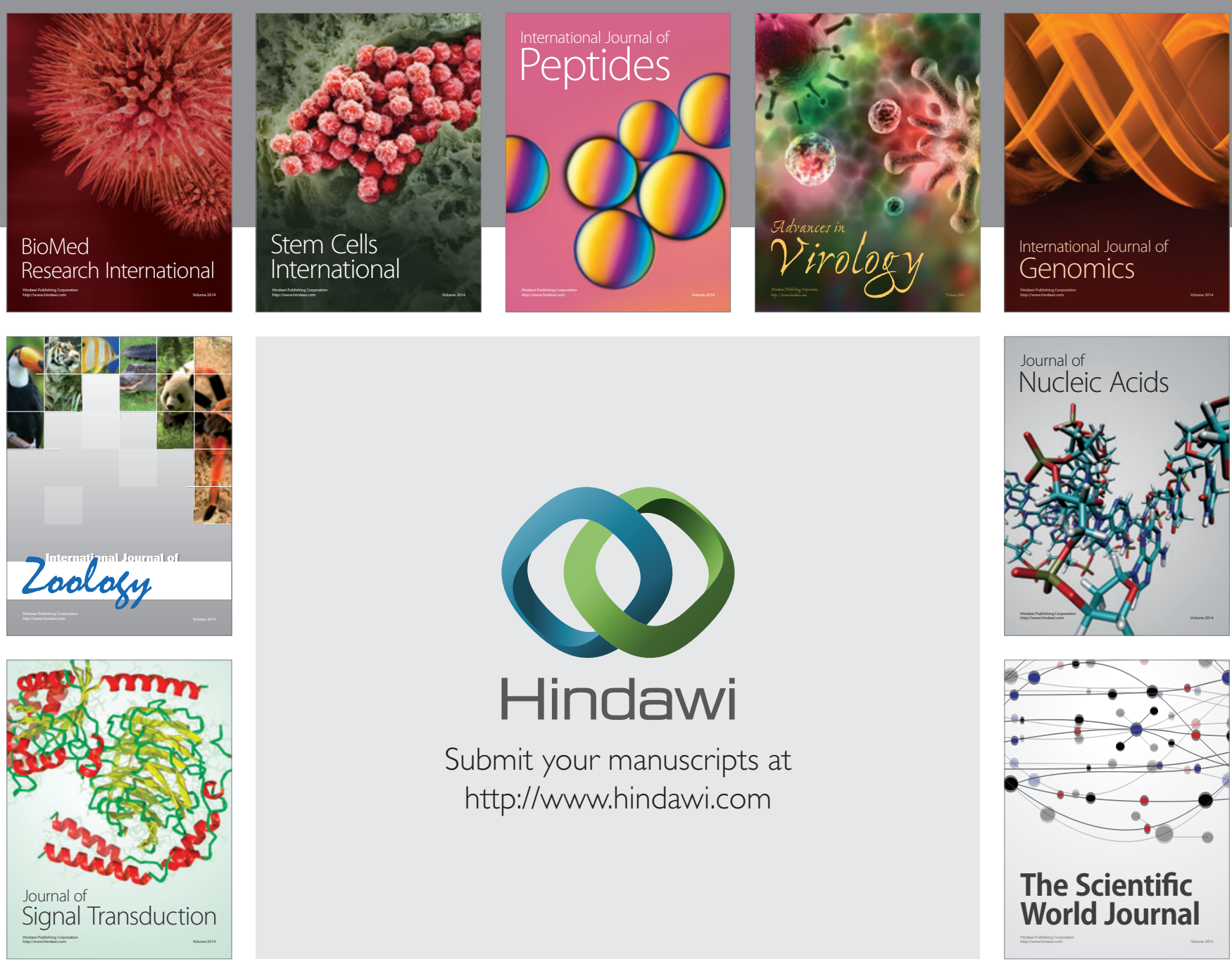

Submit your manuscripts at

http://www.hindawi.com
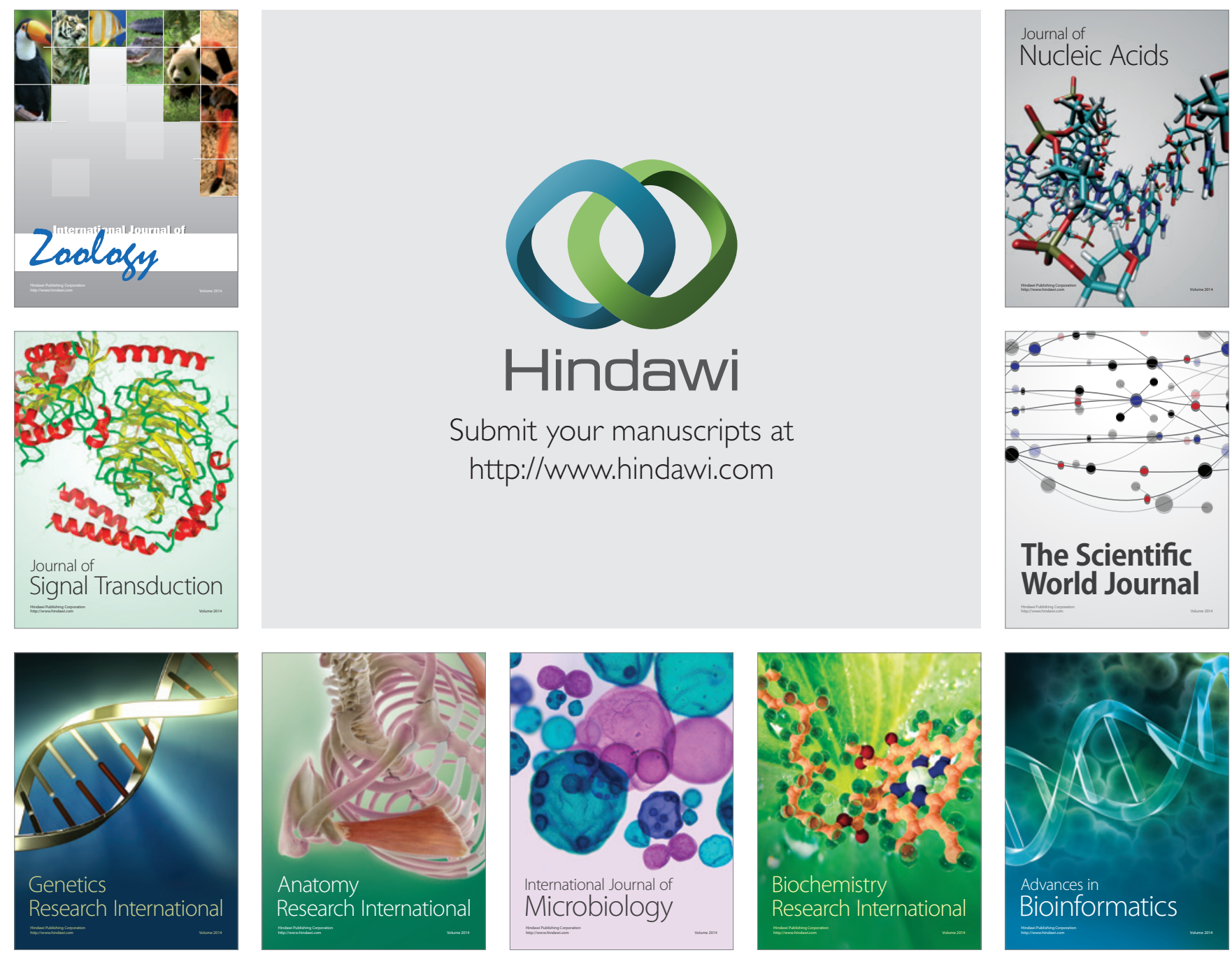

The Scientific World Journal
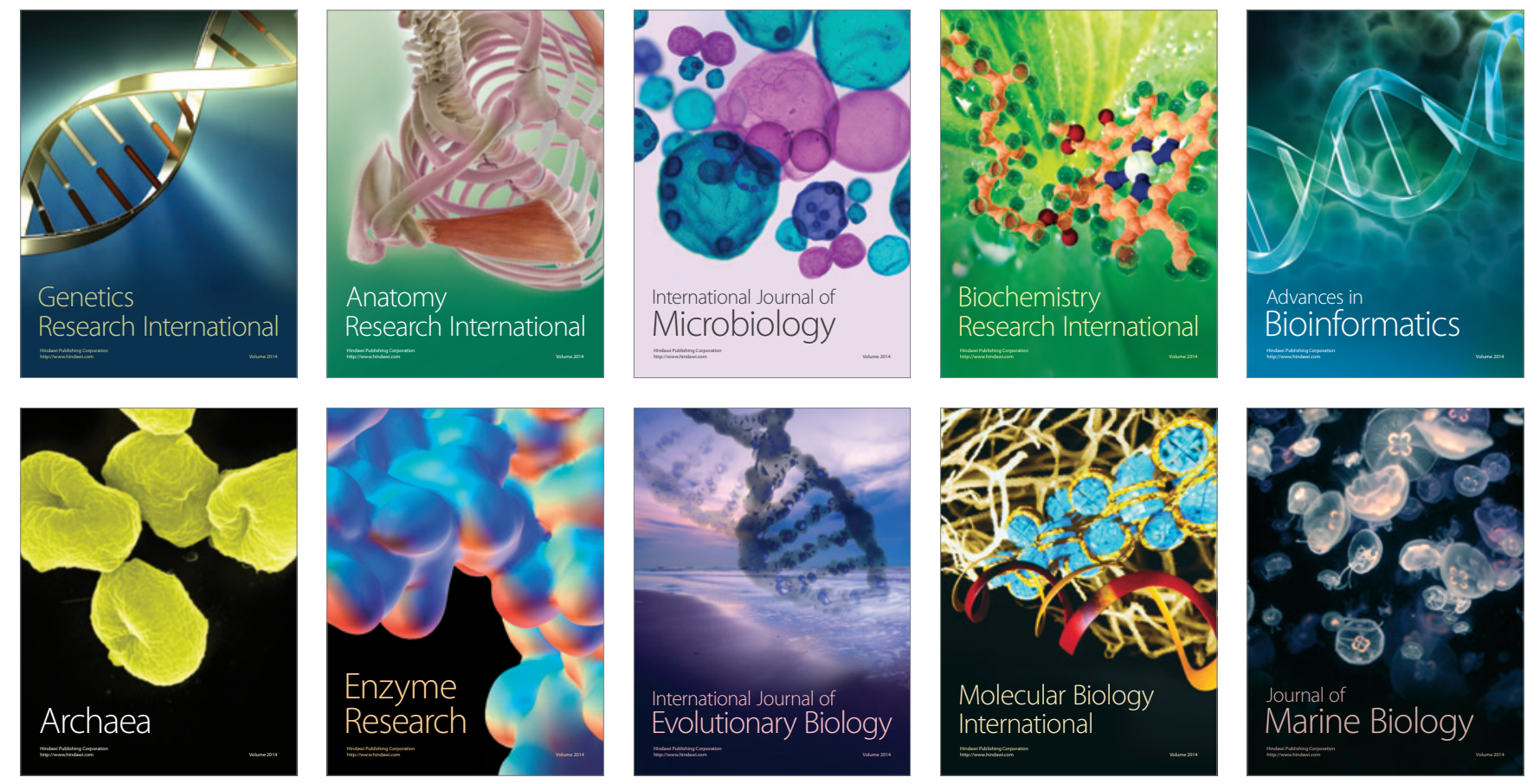